\title{
Production of marker-free transgenic Jatropha curcas expressing hybrid Bacillus thuringiensis $\delta$-endotoxin Cry1 Ab/1Ac for resistance to larvae of tortrix moth (Archips micaceanus)
}

\author{
Keyu Gu${ }^{1}$, Huizhu Mao ${ }^{1}$ and Zhongchao Yin ${ }^{1,2^{*}}$
}

\begin{abstract}
Background: The potential biofuel plant Jatropha curcas L. is affected by larvae of Archips micaceanus (Walker), a moth of the family Tortricidae. The hybrid Bacillus thuringiensis (Bt) $\delta$-endotoxin protein Cry1Ab/1Ac confers resistance to lepidopteran insects in transgenic rice.

Results: Here, we report the production of a marker-free transgenic line of J. curcas (L10) expressing Cry1Ab/1Ac using Agrobacterium-mediated transformation and a chemically regulated, Cre/loxP-mediated DNA recombination system. L10 carries a single copy of marker-free T-DNA that contains the Cry $1 A b / 1 A c$ gene under the control of a maize phosphoenolpyruvate carboxylase gene promoter ( $\left.P_{\text {Pepc }}: C r y 1 A b / 1 A c: T_{\text {Nos }}\right)$. The $P_{\text {Pepc: }}: C r y 1 A b / 1 A c: T_{\text {Nos }}$ gene was highly expressed in leaves of L10 plants. Insecticidal bioassays using leaf explants of L10 resulted in 80-100\% mortality of larvae of $A$. micaceanus at 4 days after infestation.

Conclusion: The results demonstrate that the hybrid Bt $\delta$-endotoxin protein Cry $1 \mathrm{Ab} / 1 \mathrm{Ac}$ expressed in Jatropha curcas displays strong insecticidal activity to A. micaceanus. The marker-free transgenic J. curcas line L10 can be used for breeding of insect resistance to A. micaceanus.
\end{abstract}

Keywords: Jatropha curcas, Archips micaceanus, Bacillus thuringiensis, Cry1Ab/1Ac, marker-free transformation

\section{Background}

The crystalline (Cry) proteins from Bacillus thuringiensis $(B t)$ have specifically toxic activity against numerous insect species of the orders Lepidoptera, Diptera, Coleoptera, Hymenoptera and nematodes [1]. The Cry proteins are inactive until they get solubilized by proteases in the insect's midgut at high $\mathrm{pH}(>9.5)$, releasing proteins called $\delta$-endotoxins $[2,3]$. The $\delta$-endotoxins bind to the midgut receptors, insert into the insect gut cell membrane to form ion channels or pore and cause cellular lysis due to the inflow of ions and water through the pores, which eventually kills the insects [4-6]. The insecticidal activity of the Cry proteins provides an alternative and attractive approach for pest management through the expression of Cry proteins

\footnotetext{
* Correspondence: yinzc@tll.org.sg

${ }^{1}$ Temasek Life Sciences Laboratory, 1 Research Link, National University of Singapore, Singapore 117604, Republic of Singapore

${ }^{2}$ Department of Biological Sciences, 14 Science Drive, National University of Singapore, Singapore 117543, Republic of Singapore
}

in transgenic plants. Expressions of the cry gene in tobacco and tomato are the first two reports of plants genetically engineered for insect resistance $[7,8]$. Since that, different versions of cry genes have been used to generate transgenic crops, such as corn, cotton, potato, tomato, rice and sugarcane [9]. The first Bt-derived insect-resistant transgenic tree was the transgenic poplar (Populus sp.) expressing Cry1A(a) $\delta$-endotoxin, which provided resistance against forest tent caterpillar (Malacosoma disstria) and gypsy moth (Lymantria dispar) [10,11]. Since that, different versions of cry genes have been transferred into a number of tree species, including walnut (Juglans regia) [12], European larch (Larix decidua Mill.) [13], white spruce (Picea glauca) $[14,15]$, loblolly pine (Pinus taeda L.) [16], eucalyptus (Eucalyptus camaldulensis) [17] and hybrid poplar (Populus tremula $\times$ Populus tremuloides) [18].

Jatropha curcas L. is a poisonous, semi-evergreen shrub or small tree that belongs to Euphorbiaceae family. J. curcas 
mainly grows in tropical and subtropical countries. Compared with other plants, J. curcas is a drought-resistant, non-food plant that can grow in marginal lands. J. curcas seeds contain about 25 to $40 \%$ storage lipids [19]. In recent years, J. curcas has emerged as a potential biofuel plant. However, like other crops, large plantation of J. curcas is greatly influenced by biotic and abiotic stresses. Despite the presence of toxins such as phorbol ester and curcins in J. curcas leaves and seeds, J. curcas is still attacked by insects [20-24], fungi [25] and viruses [26].

Archips is a genus of tortrix moths that belong to the family Tortricidae and have over 100 species. The leafrolling larvae of tortrix moths feed on plant leaves, causing damage to crops and trees [27]. Recently, Archips occidentalis (Walsingham) was reported to cause damage on J. curcas plants in Southern Benin [20]. In Southeast Asia, the most common tortrix moth species is Archips micaceanus (Walker) although Archips machlopis (Meyrick) and Archips tabescens (Meyrick) were also found in Malaysia [28]. A. micaceanus, also called soybean leaf-roller, is the only tortrix moth species reported in Singapore [28]. Recently, we found that $A$. micaceanus could also cause damage to J. curcas (Figure 1). Chemical pesticides are effective against the tortrix moths and larvae; however, they also kill non-target beneficial insects, especially the pollinators for $J$. curcas [29]. Previously, Bt-derived biological insecticides were used to control tortrix moths Archips argyrospilus (Walker) on apple and pear [30,31] and Archips rosanus (L.) on filberts [32]. The effectiveness of $B t$ on the two tortrix moths suggests cry gene may be used to control $A$. micaceanus on J. curcas plants.

A hybrid $c r y$ gene $C r y 1 A b / 1 A c$ was previously used to generate transgenic rice in Minghui 63, an indica cytoplasmic male sterile (CMS) restorer line, and its derived hybrid $F_{1}$ rice Shanyou 63 expressing Cry1Ab/1Ac proteins showed high protection against both leaf-folder
(Cnaphalocrocis medinalis) and yellow stem borer (Scirpophaga incertulas) [33]. Recently we produced a markerfree transgenic rice line L24 with the $P_{\text {Pepc }}$ :Cry1Ab/1Ac: $T_{\text {Nos }}$ gene using Agrobacterium-mediated transformation and a chemically regulated, Cre/loxP-mediated DNA recombination system [34]. The $P_{P e p c}: C r y 1 A b / 1 A c: T_{\text {Nos }}$ gene in L24 was mainly expressed in green tissues such as leaves and stem and provided resistance to rice leaf-folder (C. medinalis) [34]. Here, we report the adoption of similar technology to generate a marker-free transgenic line of J. curcas that expresses Cry1Ab/1Ac proteins for resistance to $A$. micaceanus.

\section{Results}

Generation of marker-free transgenic line of $J$. curcas containing $P_{\text {Pepc }}:$ Cry1Ab/1Ac: $T_{\text {Nos }}$ gene

The binary construct pCCreloxPBt, which carries a chemically regulated Cre/loxP system and a hybrid Cry $1 A b / 1 A c$ gene driven by maize phosphoenolpyruvate carboxylase (PEPC) gene promoter $\left(P_{\text {Pepc }}: C r y 1 A b / 1 A c: T_{N o s}\right)$, was used to produce marker-free transgenic rice line L24 that specifically expresses the Cry $1 \mathrm{Ab} / 1 \mathrm{Ac}$ proteins in leaves and stem [34]. Theoretically, the marker (Hpt gene)-containing loxP fragment in T-DNA region of pCCreloxPBt in transgenic plants can be removed by $\beta$-estradiol-regulated Cre/ loxP-mediated excision, which yields marker-free T-DNA in transgenic plants [34]. The marker-free T-DNA is detected by PCR amplification of P1-P4 fragment (385 bp) flanking the remaining loxP site after DNA recombination, while the marker-containing T-DNAs, T-DNAs that have undergone incomplete loxP fragment excision and truncated T-DNAs are detected by PCR amplification of the P1-P2 (534 bp) fragment flanking the loxP site at the left border of T-DNA and/or the P3-P4 (460 bp) fragment flanking the loxP site adjacent to the maize PEPC gene promoter [34]. In this study, pCCreloxPBt was used to
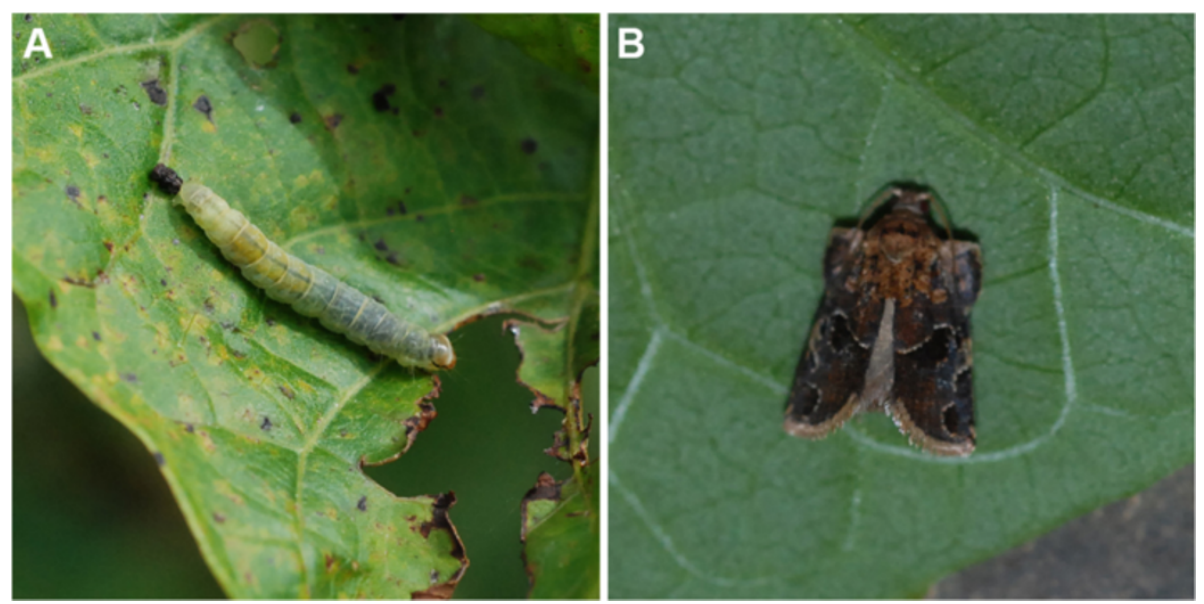

Figure 1 Archips micaceanus at larva (A) and adult (B) stages on J. curcas leaves. 
produce transgenic J. curcas plants via Agrobacterium-mediated transformation [35]. After $\beta$-estradiol-regulated Cre/ loxP-mediated excision of the loxP fragment, a total of twenty putative transgenic $\mathrm{T}_{0}$ plants were obtained. The $20 \mathrm{~T}_{0}$ plants were screened by PCR for the presence of the $\mathrm{Cry} 1 \mathrm{Ab} / \mathrm{AAc}$ and $\mathrm{Hpt}$ genes as well as for the excision of the loxP fragment, which was detected by the amplification of P1-P4 fragment [34]. All the $20 \mathrm{~T}_{0}$ plants carried the coding region of the $C r y 1 A b / 1 A c$ gene (Table 1 ). Only one plant, $\mathrm{T}_{0}-20$, showed PCR amplification of the $\mathrm{Cr} y 1 \mathrm{Ab} / 1 \mathrm{Ac}$ gene and the P1-P4 fragment, but not the $H p t$ gene (Table 1). Twelve $\mathrm{T}_{0}$ plants had PCR amplification of both $\mathrm{Cry} 1 \mathrm{Ab} / 1 \mathrm{Ac}$ and $\mathrm{Hpt}$ genes, but not the P1-P4 fragment, indicating that they carried marker-containing T-DNA only (Table 1). Six $\mathrm{T}_{0}$ plants gave amplification of both CrylAb/ $1 A c$ and Hpt genes, as well as the P1-P4 fragment (Table 1). These plants should contain multiple copies of T-DNA and at least one copy had undergone loxP fragment excision. In addition, plant $\mathrm{T}_{0}-1$ had PCR amplification of the Cry1Ab/ $1 A c$ gene only, but not the Hpt gene or the P1-P4 fragment (Table 1). This plant might carry a truncated T-DNA

Table 1 PCR analysis of the $T_{0}$ transgenic plants

\begin{tabular}{|c|c|c|c|}
\hline$T_{0}$ plant & Cry $1 A b / 1 A c^{1}$ & $\mathrm{P} 1-\mathrm{P} 4^{2}$ & $\mathrm{Hpt}^{3}$ \\
\hline$\overline{p C C r e l o x P B t}{ }^{4}$ & + & - & + \\
\hline MD44 & - & - & - \\
\hline 1 & + & - & - \\
\hline 2 & + & - & + \\
\hline $2 B$ & + & - & + \\
\hline $4 \mathrm{~A}$ & + & - & + \\
\hline $4 B$ & + & - & + \\
\hline 6 & + & - & + \\
\hline 8 & + & - & + \\
\hline 10 & + & + & + \\
\hline 11 & + & + & + \\
\hline 12 & + & - & + \\
\hline 13 & + & - & + \\
\hline 19 & + & - & + \\
\hline 20 & + & + & - \\
\hline 21 & + & + & + \\
\hline 24 & + & - & + \\
\hline 33 & + & + & + \\
\hline 37 & + & + & + \\
\hline 38 & + & + & + \\
\hline 39 & + & - & + \\
\hline 40 & + & - & + \\
\hline
\end{tabular}

${ }^{1}$ The primers for detecting the presence of the Cry $1 A b / 1 A c$ gene were Bt F1 and $\mathrm{Bt} \mathrm{R} 1$; ${ }^{2}$ the primers for detecting the excision of the loxP fragment or the presence of $\mathrm{P} 1-\mathrm{P} 4$ fragment were $\mathrm{P} 1$ and $\mathrm{P} 4$ [34]; ${ }^{3}$ the primers for detecting the presence of the Hpt gene were $\mathrm{Hpt} \mathrm{F}$ and Hpt910-1; ${ }^{4}$ binary construct used for transgenic J. curcas production [34]. containing the $C r y 1 A b / 1 A c$ gene only, which did not result from precise excision of the lox $P$ fragment.

The expression of the Cry1Ab/1Ac proteins in the $20 \mathrm{~T}_{0}$ plants was detected by western blot analysis. The initial results indicated that only one $\mathrm{T}_{0}$ plant, $\mathrm{L} 10-\mathrm{T}_{0}$, had Cry1 $\mathrm{Ab} /$ 1Ac expression with the expected molecular size at about $68 \mathrm{kDa}$; the remaining $\mathrm{T}_{0}$ plants either did not show any expression of the Cry1 Ab/1Ac protein or expressed truncated Cry1Ab/1Ac proteins (data not shown). Transgenic L10- $\mathrm{T}_{0}$ was selected for further study, while the other undesirable $T_{0}$ plants were discarded. $L 10-T_{0}$ had five copies of T-DNA detected by southern blot analysis using the restriction enzyme Ncol, which has cutting sites upstream only of $P_{\text {Pepc }}: \operatorname{Cry} 1 A b / 1 A c: T_{\text {Nos }}$, and the Cry $1 A b / 1 A c$ gene probe (Figure 2A). The above-mentioned PCR analysis also indicates that $\mathrm{L} 10-\mathrm{T}_{0}$ contains both marker-free and marker-containing T-DNAs (Table 1). We then performed genetic analysis in order to obtain functional and markerfree transgenic $\mathrm{T}_{1}$ plants that carry the $P_{\text {Pepc }}$ Cry $1 A b / 1 A c$ : $T_{N o s}$ gene only. Twenty $\mathrm{T}_{1}$ progeny of $\mathrm{L} 10-\mathrm{T}_{0}$ were obtained and they were screened by PCR for individuals that contained only marker-free T-DNA (Table 2). Three $\mathrm{T}_{1}$ plants, $\mathrm{L}_{10}-\mathrm{T}_{1}-5, \mathrm{~L} 10-\mathrm{T}_{1}-10$ and $\mathrm{L} 10-\mathrm{T}_{1}-18$, showed PCR amplification of the Cry1Ab/1Ac gene and the P1-P4 fragment, but not for P1-P2 and P3-P4 fragment (Table 2 and Figure 3; data for $\mathrm{L}_{10-\mathrm{T}_{1}-5}$ are not shown). The results indicate that the three $T_{1}$ plants have inherited the markerfree T-DNA from $\mathrm{L} 10-\mathrm{T}_{0}$. $\mathrm{L} 10-\mathrm{T}_{1}-10$ and $\mathrm{L} 10-\mathrm{T}_{1}-18$ were selected for further analysis, whereas $\mathrm{L}_{10}-\mathrm{T}_{1}-5$ died from pathogen infection. Southern blot analysis indicated that both $\mathrm{L} 10-\mathrm{T}_{1}-10$ and $\mathrm{L} 10-\mathrm{T}_{1}-18$ carry one copy of T-DNA, which is the marker-free T-DNA identified by PCR analysis (Figure 2B and C). More importantly, the expected $3.5-\mathrm{kb}$ SphI-KpnI fragment was detected in $\mathrm{L}_{10-\mathrm{T}_{1}-10}$ and L10$\mathrm{T}_{1}-18$ by southern blot analysis using restriction enzymes SphI and KpnI and the Cry1Ab/1Ac probe (Figure 2D), indicating that the two marker-free transgenic plants contain the intact $P_{\text {Pepc }}:$ Cry $1 A b / 1 A c: T_{N o s}$ gene. For both PCR and southern blot analyses, no signal was detected with nontransgenic MD44 plants (Table 2, Figure 2 and Figure 3).

\section{Expression of the $P_{\text {Pepc }}: C r y 1 A b / 1 A c: T_{\text {Nos }}$ gene in marker-free plants $\mathrm{L}_{10}-\mathrm{T}_{1}-10$ and $\mathrm{L} 10-\mathrm{T}_{1}-18$}

The transcripts of the $P_{\text {Pepc }}$ Cry $1 A b / 1 A c: T_{\text {Nos }}$ gene in L10$\mathrm{T}_{1}-10$ and $\mathrm{L} 10-\mathrm{T}_{1}-18$ were detected by northern blot analysis as well as by real-time quantitative reverse transcription PCR (qRT-PCR) (Figure 4A and B). No signal was detected in non-transgenic MD44 plants in either of the two experiments (Figure 4A and B). The Cry1Ab/1Ac proteins expressed in transgenic J. curcas plants were detected by western blot analysis and anti-CRY1Ab polyclonal anti-

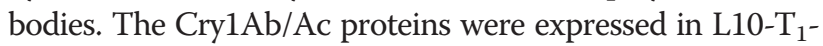
10 and $\mathrm{L} 10-\mathrm{T}_{1}-18$, which had similar molecular size to that of Cry1Ab/1Ac expressed in rice (Figure 5). No Cry1Ab/ 

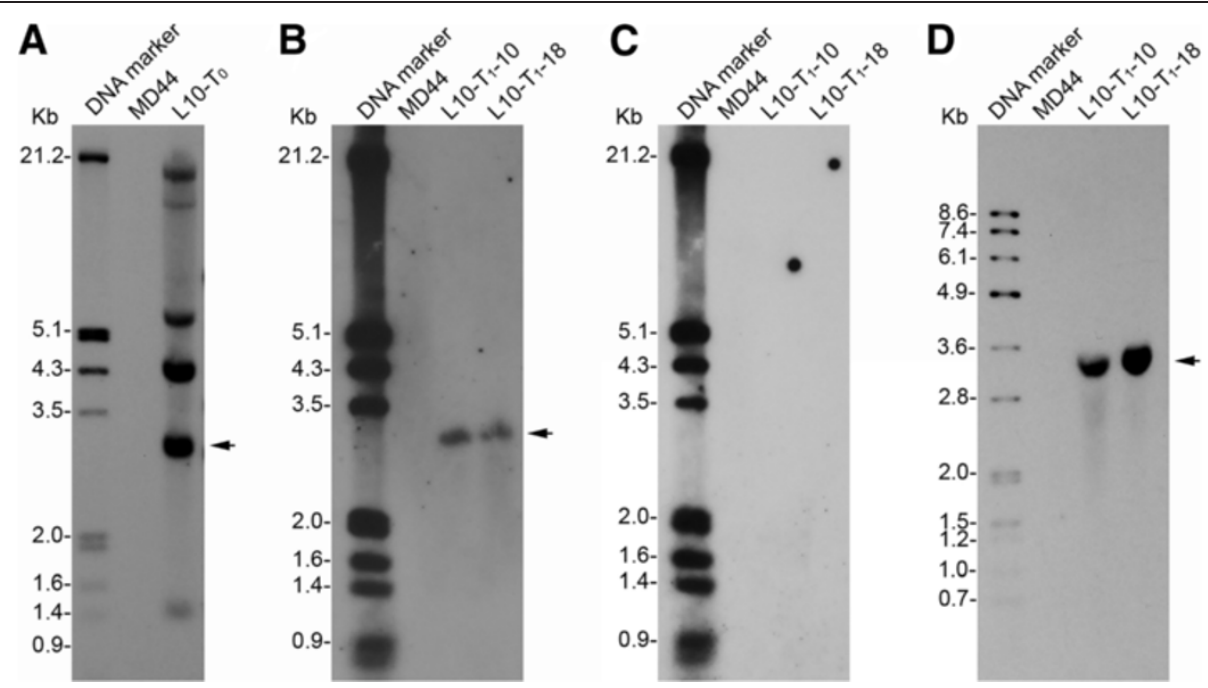

Figure 2 Southern blot analysis of transgenic Cry 1Ab/1Ac plants of $J$. curcas. (A) Detection of T-DNA copy number in transgenic To plant L10 $\left(\mathrm{L} 10-\mathrm{T}_{0}\right)$. Genomic DNA samples of $\mathrm{L} 10-\mathrm{T}_{0}$ and cultivar MD44 were digested with restriction enzyme Ncol. The southern blot was hybridized with a DNA probe derived from the Cry $1 A b / 1 A c$ gene. Arrow indicates the T-DNA copy that was putative marker-free (see below), which was selected for further study. (B) Transmission of the marker-free T-DNA in the $T_{1}$ progeny of L10. Southern blot analysis was carried out using the restriction enzyme Ncol and the Cry $1 A b / 1 A c$ probe. L10-T $T_{1}-10$ and L10-T $1-18$ are two individual $T_{1}$ plants of L10. (C) Detection of Hpt gene in $T_{1}$ plants $L 10-T_{1}-10$ and $L 10-T_{1}-18$ by southern blot analysis. The same southern blot in (B) was stripped and then re-hybridized with an Hpt gene probe. (D) Detection of the intact $P_{P e p c:}$ $C r y 1 A b / 1 A c: T_{N o s}$ gene in the marker-free $T_{1}$ progeny of $L 10$. Genomic DNA samples of $L 10-T_{1}-10, L 10-T_{1}-18$ and MD44 were digested with restriction enzymes Kpnl and Sphl. The southern blot was hybridized with the CrylAb/1Ac probe. The expected size of the Kpnl-Sphl fragment of the $P_{\text {Pepc: }}$ CrylAb/1Ac: $T_{\text {Nos }}$ gene is $3452 \mathrm{bp}$.

1Ac signal was detected in non-transgenic MD44 plants (Figure 5). However, a non-specific band with molecular size at about $50 \mathrm{kDa}$ was detected by anti-CRY1Ab polyclonal antibodies in both MD44 and transgenic J. curcas plants (Figure 5). The results demonstrated that the $P_{\text {Pepc }}$ : Cry $1 \mathrm{Ab} / \mathrm{Ac:} \mathrm{T}_{\mathrm{Nos}}$ gene expresses normally in leaf tissues of transgenic J. curcas plants.

\section{Cry1 Ab/1Ac expressed in J. curcas provides resistance to A. micaceanus}

A. micaceanus larvae, at the second to third instar stages, were collected from J. curcas plants grown in an in-house farm and used for insecticidal bioassay. The larvae were fed with leaf explants from MD44 or $\mathrm{L}_{10} \mathrm{~T}_{1}-10$ (Figure 6A). After 4 days of infestation, the larvae feeding on nontransgenic MD44 completely ate up the two leaf explants in each beaker, whereas the larvae feeding on $\mathrm{L} 10-\mathrm{T}_{1}-10$ caused little damage to the leaf explants (Figure 6B and C). In total, 14 of the $15 \mathrm{~A}$. micaceanus larvae feeding on MD44 in the three repeated experiments remained alive and healthy, and one larva in experiment I transformed into a pupa, which might be due to the third instar larvae used for this experiment (Figure 6D; Table 3). On the contrary, 14 of the 15 A. micaceanus larvae feeding on $\mathrm{L}_{10}-\mathrm{T}_{1}-10$ died at 2 to 3 days after infestation (Figure 6E; Table 3). Only one larva survived and transformed into a pupa after feeding on $\mathrm{L}_{10}-\mathrm{T}_{1}-10$ in experiment I (Table 3). The larvae mortality in explants of transgenic J. curcas ranged from 80 to $100 \%$ in the three repeated experiments (Table 3). The bioassay results clearly demonstrated that the Cry1Ab/1Ac proteins expressed in transgenic J. curcas have strong insecticide activity against $A$. micaceanus larvae.

\section{Discussion}

Using Agrobacterium-mediated transformation and a chemically regulated, Cre/loxP-mediated DNA recombination system, we have obtained one transgenic $J$. curcas line that contains a single copy of the $P_{\text {Pepc }}: \mathrm{Cry} 1 \mathrm{Ab} / 1 \mathrm{Ac}$ : $T_{\text {Nos }}$ gene within a marker-free T-DNA. Twenty $\mathrm{T}_{0}$ plants were produced in this study but one marker-free line was obtained. The efficiency of obtaining a marker-free transgenic line was only $5 \%$. The major reason for the low efficiency in obtaining marker-free transgenic line may be due to the inefficient excision of the loxP fragment in the T-DNA after $\beta$-estradiol induction, which occurred in 7 of the $20 \mathrm{~T}_{0}$ plants obtained (Table 1 ). In this study, the $\beta$-estradiol induction was applied on the hygromycin-resistant shoots rather than on the hygromycin-resistant calli in order to obtain as many transgenic plants as possible. In this case, the $\beta$-estradiol might not be able to uniformly and efficiently access all types of cells, especially the germline cells in the regenerated shoots. Further study may be required to test the introduction of $\beta$-estradiol induction on the hygromycin-resistant calli rather than the hygromycin-resistant shoots. Another reason could be the result of incomplete loxP fragment excision from T-DNA 
Table 2 PCR analysis of the L10 $T_{1}$ transgenic plants

\begin{tabular}{|c|c|c|c|c|c|}
\hline $\mathrm{T}_{1}$ plant & P1-P2 ${ }^{1}$ & $\mathrm{P}-\mathrm{P4}^{2}$ & $\mathrm{P} 1-\mathrm{P} 4^{3}$ & $H p t^{4}$ & Cry $1 A b / 1 A c^{5}$ \\
\hline $\mathrm{pCCreloxPBt}^{6}$ & + & + & - & + & + \\
\hline MD44 & - & - & - & - & - \\
\hline L10-T $1-1$ & - & + & - & + & + \\
\hline L10-T $1-2$ & - & - & + & + & + \\
\hline L10-T,-3 & - & + & - & + & + \\
\hline $\mathrm{L} 10-\mathrm{T}_{1}-4$ & - & + & + & + & + \\
\hline $\mathrm{L} 10-\mathrm{T}_{1}-5$ & - & - & + & - & + \\
\hline $\mathrm{L} 10-\mathrm{T}_{1}-6$ & - & + & - & + & + \\
\hline L10-T $1-7$ & - & + & - & + & + \\
\hline$L 10-T_{1}-8$ & - & + & - & + & + \\
\hline L10-T $1-9$ & - & + & - & + & + \\
\hline $\mathrm{L} 10-\mathrm{T}_{1}-10$ & - & - & + & - & + \\
\hline L10-T $1-11$ & - & + & + & + & + \\
\hline $\mathrm{L} 10-\mathrm{T}_{1}-12$ & - & + & - & + & + \\
\hline $\mathrm{L} 10-\mathrm{T}_{1}-13$ & - & + & - & + & + \\
\hline L10-T $1-14$ & - & - & - & - & - \\
\hline $\mathrm{L} 10-\mathrm{T}_{1}-15$ & - & + & + & + & + \\
\hline$L 10-T_{1}-16$ & - & + & + & + & + \\
\hline $\mathrm{L} 10-\mathrm{T}_{1}-17$ & - & + & + & + & + \\
\hline $\mathrm{L} 10-\mathrm{T}_{1}-18$ & - & - & + & - & + \\
\hline $\mathrm{L} 10-\mathrm{T}_{1}-19$ & - & + & + & + & + \\
\hline L10-T $1-20$ & - & + & + & + & + \\
\hline
\end{tabular}

${ }^{1}$ The primers for detecting the presence of $\mathrm{P} 1-\mathrm{P} 2$ fragment were $\mathrm{P} 1$ and $\mathrm{P} 2$ [34]; ${ }^{2}$ the primers for detecting the presence of P3-P4 fragment were P3 and P4 [34]; ${ }^{3}$ the primers for detecting the excision of the loxp fragment or the presence of $\mathrm{P} 1-\mathrm{P} 4$ fragment were $\mathrm{P} 1$ and P4 [34]; ${ }^{4}$ the primers for detecting the presence of the Hpt gene were Hpt $\mathrm{F}$ and $\mathrm{Hpt} 910-1$; ${ }^{5}$ the primers for detecting the presence of the $\mathrm{Cry} 1 \mathrm{Ab} / 1 \mathrm{Ac}$ gene were $\mathrm{Bt} \mathrm{F} 1$ and $\mathrm{Bt} \mathrm{R} 1$; ${ }^{6}$ binary construct used for transgenic J. curcas production [34].

in transgenic plants that contain multiple copies of $\mathrm{T}$ DNA. In this study, the two marker-free $\mathrm{T}_{1}$ plants, L10$\mathrm{T}_{1}-10$ and $\mathrm{L} 10-\mathrm{T}_{1}-18$, were obtained from $\mathrm{T}_{1}$ progeny of $\mathrm{L} 10-\mathrm{T}_{0}$, which contained at least five copies of T-DNA. Finally, truncated T-DNA integration containing only one loxP site may make it impossible to perform Cre/loxP-mediated DNA recombination, which further reduces the efficiency of obtaining marker-free transgenic plants. Incomplete loxP fragment excision may be unavoidable due to the common presence of multiple T-DNA insertion and truncated T-DNA integration [34,36,37]. Nevertheless, the marker-free transgenic J. curcas plants generated in this study reduce the biosafety concerns of the marker gene on the environments.

Due to the presence of toxins such as phorbol ester and curcin in seeds, the storage lipids from J. curcas seeds are mainly used as biofuel or in other industrial applications rather than as human food or animal feed. The $B t \delta$-endotoxin, as an effective biological insecticide, has been successfully used for generation of transgenic plants for

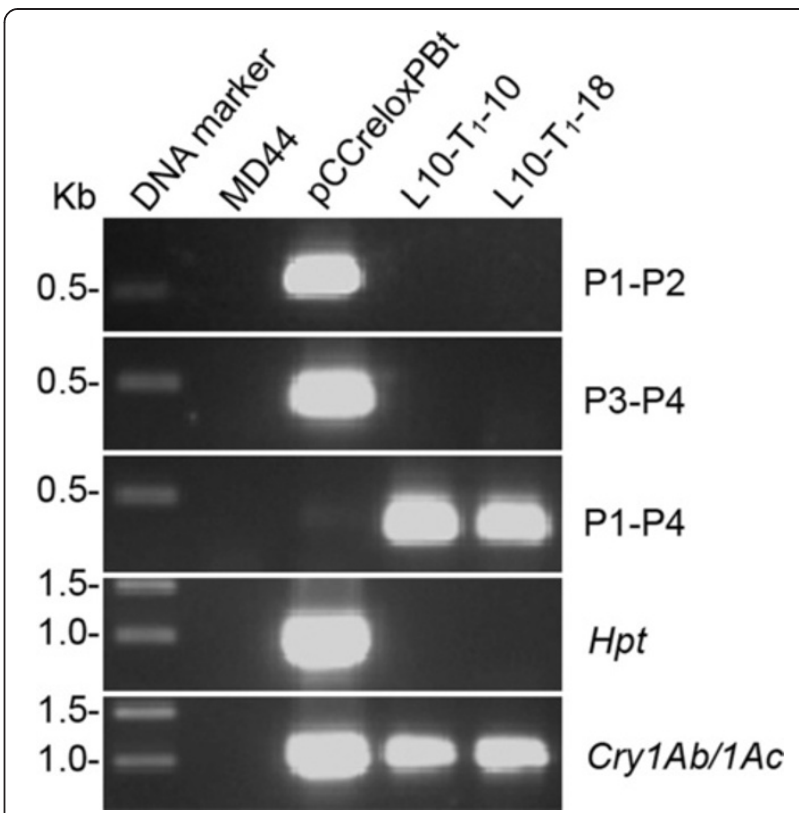

Figure 3 Detection of loxP fragment excision by PCR. Genomic DNA samples from the putative marker-free $T_{1}$ plants $L 10-T_{1}-10$ and L10-T $T_{1}-18$ were amplified by PCR for detection of Cre/loxP-mediated loxP fragment excision using primer pairs P1/P2, P3/P4 and P1/P4 [34]. The presence or absence of the $H p t$ and $C r y 1 A b / 1 A c$ genes were also detected by PCR. Plasmid DNA of pCCreloxPBt and genomic DNA from MD44 were used as the controls. Primers are listed in Table 4.

insect resistance in both crops and trees. Therefore, the utilization of the $c r y$ gene in developing transgenic J. curcas for insect resistance is an ideal method for insect control and will unlikely give rise to biosafety concern in the food chain of human beings. In this study, the Cry1Ab/ 1Ac proteins produced in transgenic J.curcas plants had strong insecticidal activity to $A$. micaceanus larvae. Previously, the hybrid Cry protein expressed in transgenic rice showed strong larvicidal activity that kills lepidopteran pests, the most serious of which include the yellow stem borer (S. incertulas), the striped stem borer (Chilo suppressalis) and rice leaffolder (C. medinalis) [33,34,38]. The Cry proteins from $B t$ have been found to show specifically toxic activity against numerous insect species of the orders Lepidoptera, Diptera, Coleoptera, Hymenoptera and nematodes [1]. It was reported that there are six families of Coleoptera and three families of Lepidoptera that can attack J. curcas plants [20]. Therefore, in the future it is worth testing whether the transgenic $J$. curcas generated in this study can provide insecticidal activity for these insects of $J$. curcas.

\section{Conclusion}

We have produced one marker-free transgenic J. curcas line that carries a single copy of the $P_{\text {Pepc }}: C r y 1 A b / 1 A c: T_{\text {Nos }}$ gene. The Cry1 Ab/1Ac proteins expressed in the transgenic J. curcas line provide high resistance to A. micaceanus 

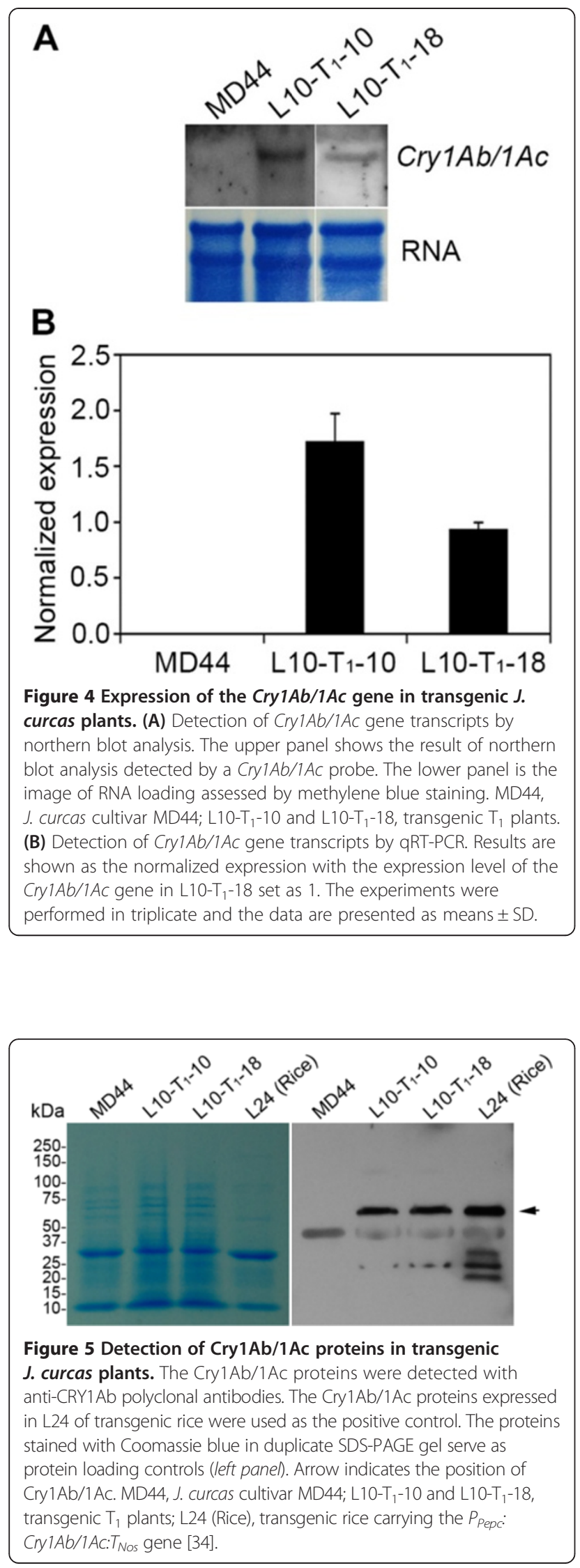

larvae. The marker-free transgenic line, designed as L10 for further study, can be used for J. curcas breeding for insect resistance to $A$. micaceanus and probably for other $B t \delta$ endotoxin-sensitive insects on J. curcas plants.

\section{Materials and methods}

Plant materials and growth conditions

J. curcas L. cv. MD44 was used for J. curcas transformation. MD44 and transgenic J. curcas plants were grown in the greenhouse under natural climate conditions at a temperature of 30 to $32^{\circ} \mathrm{C}$ for $12.5 \mathrm{~h}$ (light) and 24 to $26^{\circ} \mathrm{C}$ for $11.5 \mathrm{~h}$ (dark).

\section{Plant transformation}

The binary construct pCCreloxPBt [34] was used for MD44 transformation. pCCreloxPBt carries a $P_{\text {Pepc }}$ : Cry $1 \mathrm{Ab} / 1 \mathrm{Ac}: \mathrm{T}_{\text {Nos }}$ gene and a chemically regulated Cre/ loxP system for the excision of the selection marker gene [34]. Agrobacterium-mediated transformation of $J$. curcas was carried out according to the method described previously [35]. In brief, the cotyledon discs at the size of $0.3 \times 0.3 \mathrm{~cm}^{2}$ were co-cultivated with Agrobacterium tumefaciens strains AGL1 harboring pCCreloxPBt on co-cultivation medium [39] for 2 to 3 days at $22^{\circ} \mathrm{C}$ in darkness. The co-cultivated cotyledon discs were rinsed thoroughly with sterile water and then with suspension medium containing $300 \mathrm{mg} / \mathrm{L}$ cefotaxime [39]. Cotyledon discs were cultured on callus formation medium [39] at $25^{\circ} \mathrm{C}$ in darkness for 3 weeks. The cotyledon discs carrying newly emerged hygromycin-resistant calli were transferred onto shoot regeneration medium I [39] and cultured for 3 weeks at $25^{\circ} \mathrm{C}$ under 16-h light/8-h dark cycles. The regenerated shoots were sub-cultured on shoot regeneration medium II [39]. The hygromycinresistant shoots at about 2 to $3 \mathrm{~mm}$ were transferred onto $\beta$-estradiol induction medium without hygromycin [39] to induce marker excision. After 2 weeks, the $\beta$-estradioltreated shoots were transferred back to the shoot regeneration medium II without hygromycin [39]. After 4 weeks, the regenerated shoots were transferred onto shoot elongation medium [39] for elongation and bud multiplication. The elongated shoots at about $2.5-\mathrm{cm}$ length were rooted on rooting medium [39]. The putative transgenic plants with a healthy root system were eventually transplanted into soil-filled pots in the greenhouse.

\section{PCR analysis}

PCR analysis for the presence of transgenes as well as Cre/ loxP-mediated DNA recombination in transgenic plants was carried out according to the methods described previously [34]. The PCR primers used in this study are listed in Table 4. 


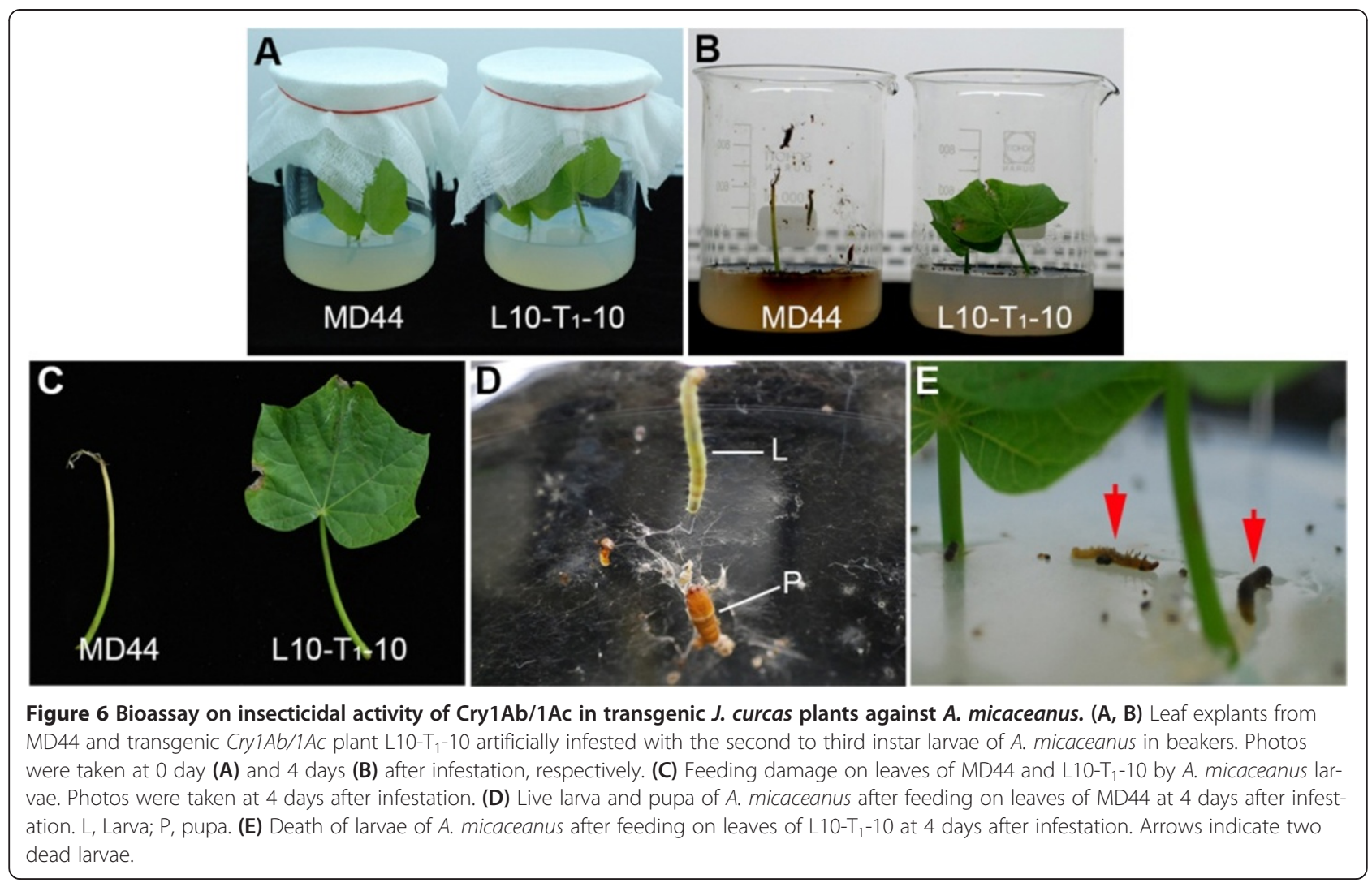

\section{Southern blot analysis}

J. curcas genomic DNA was isolated from leaf tissues as described previously [40]. About $2 \mu \mathrm{g}$ of DNA was digested with proper restriction enzymes, separated on $0.8 \%$ agarose gel and then blotted to Hybond ${ }^{\mathrm{Tm}}-\mathrm{N}^{+}$nylon membrane (Amersham Biosciences, Little Chalfont, Buckinghamshire, UK). Southern blots were hybridized with DIG-labelled DNA probes for $C r y 1 A b / 1 A c$ and hygromycin phosphotransferase gene $(\mathrm{Hpt})$, respectively, according to standard

Table 3 Bioassay using artificial infestation of $\boldsymbol{A}$. micaceanus larvae on leaf explants of MD44 and transgenic plant $\mathrm{L}_{10}-\mathrm{T}_{\mathbf{1}}-10$

\begin{tabular}{llll}
\hline Plant & $\begin{array}{l}\text { Larvae upon } \\
\text { infestation, } \\
\text { number }\end{array}$ & $\begin{array}{l}\text { Larvae or pupa } \\
\text { after infestation, } \\
\text { number }\end{array}$ & Mortality $\mathbf{\%}^{1}$ \\
\hline Experiment I & 5 & 4 larvae +1 pupa & 0 \\
MD44 & 5 & 1 pupa & $80 \%$ \\
L10-T $_{1}-10$ & 5 & 5 larvae & 0 \\
Experiment II & 5 & 0 & $100 \%$ \\
MD44 & & & 0 \\
L10-T $_{1}-10$ & 5 & 5 larvae & $100 \%$ \\
Experiment III & 5 & 0 & \\
MD44 & & & \\
L10-T $_{1}-10$ & & & \\
\hline
\end{tabular}

${ }^{1}$ Viability and mortality of insects were scored at 4 days after infestation. procedures. The primer pairs for amplification of DNA probes were Bt F1/Bt R1 for the Cry1Ab/1Ac gene and Hpt F/Hpt910-1 for the Hpt gene, respectively (Table 4).

\section{Northern blot analysis}

Total RNA was isolated from leaf tissues of J. curcas using the methods described previously [40]. About $10 \mu \mathrm{g}$ total RNA was fractionated on a $1.2 \%$ formaldehyde agarose gel and blotted onto a Hybond ${ }^{\mathrm{TM}} \mathrm{N}^{+}$membrane (Amersham

Table 4 DNA primers used in this study

\begin{tabular}{lll}
\hline Primer & Nucleotide sequence (5'-3') & Reference \\
\hline P1 & GAATTGTCGAGGTCGAGATC & {$[34]$} \\
P2 & ATAGTGAAACAGGGGCAATGG & {$[34]$} \\
P3 & ACGGCGAGTTCTGTTAGGTC & {$[34]$} \\
P4 & GAAGATACACGGATTGAGGAGAG & {$[34]$} \\
Hpt F & AAAAAGCCTGAACTCACCGCGACGT & This study \\
Hpt910-1 & TACTTCTACACAGCCATCGGTCCA & This study \\
Bt F1 & AGGCCATACAACTGCTTGAG & This study \\
Bt R1 & CTGTAGACACCCTGACCTAG & This study \\
Bt F2 & TCATCCATCTTCTCCAATACAG & This study \\
Bt R2 & GTAACTGGAATGAACTCGAATC & This study \\
JCActin F1 & TAATGGTCCCTCTGGATGTG & This study \\
JcActin R1 & AGAAAAGAAAAGAAAAAAGCAGC & This study \\
\hline
\end{tabular}


Biosciences). The northern blot hybridization and the labeling of the $C r y 1 A b / 1 A c$ gene probe were similar to the methods described for the southern blot analysis.

\section{Real-time quantitative reverse transcription PCR (qRT-PCR)} qRT-PCR was carried out according to the method described previously with minor modification [41]. The first strand cDNA was synthesized using iScript cDNA synthesis kit (Bio-Rad, Hercules, CA, USA). PCR reaction $(15 \mu \mathrm{l})$ was conducted on a CFX96 real-time system containing $2 \mu \mathrm{l}$ first strand cDNA templates, $1 \times$ SsoFast EvaGreen supermix (Bio-Rad) and $500 \mathrm{nM}$ forward primer Bt F2 and reverse primer Bt R2 (Table 4). The actin gene 1 (JcActin1) of J. curcas was used as control. The primer pair for the Cry1Ab/1Ac gene was Bt F2/Bt R2, and the primer pair for the JcActin1 gene was JcActin F1/JcActin R1 (Table 4).

\section{Western blot analysis}

Total proteins were extracted from $J$. curcas leaves with a homogenization buffer $(0.1 \mathrm{M}$ Tris- $\mathrm{HCl}, \mathrm{pH} 8.0,0.01 \mathrm{M}$ $\mathrm{MgCl}_{2}, 18 \%$ (w/v) sucrose, $40 \mathrm{mM} \beta$-mercaptoethanol). Total protein concentration was determined with the Bradford method [42]. About $10 \mu \mathrm{g}$ of each protein sample was separated on an $8 \%$ SDS-PAGE, followed by blotting onto polyvinylidene fluoride (PVDF) membranes (Bio-Rad). The Cry1Ab/1Ac proteins from the rice line L24, a marker-free transgenic line carrying the $P_{\text {Pepc }}$ : Cry1Ab/1Ac: $T_{\text {Nos }}$ gene [34], served as the positive control. Cry1Ab/1Ac proteins were detected with anti-CRY1Ab polyclonal antibodies (Abcam, Cambridge, UK) and horseradish peroxidase-coupled secondary antibodies (Bio-Rad).

\section{Insect bioassay}

A beaker method was utilized to check if the Cry1Ab/ 1 Ac proteins expressed in the transgenic J. curcas plants had insecticidal activity towards A. micaceanus larvae. Leaf explants from transgenic J. curcas plants or nontransgenic MD44 plants were sterilized and put on $1 \%$ Agar medium in beakers. Five, second to third instar $A$. micaceanus larvae, collected from J. curcas plants grown in an inhouse farm were fed onto J. curcas leaves. The beakers were sealed with cheese cloth to prevent the larvae from escaping. The feeding assay was conducted in a growth chamber at a temperature of $28^{\circ} \mathrm{C}$, relative humidity of $80 \%$ and photoperiod of $12 \mathrm{~h}$. Damage on leaf tissues and the larval mortality were observed and photographed at 4 days after infestation. The experiment was repeated three times and the results are representative of each independently conducted experiment.

\section{Abbreviations}

bp: base pairs; Bt: Bacillus thuringiensis; PEPC: phosphoenolpyruvate carboxylase; Cry: Crystalline; qRT-PCR: real-time quantitative reverse transcription PCR.
Competing interests

The authors declare no competing financial interests.

\section{Authors' contributions}

$\mathrm{YZ}$ and GK designed the experiments. GK and MH conducted the experiments. GK and $Y Z$ analyzed the data and wrote the article. All the authors have read and approved the final manuscript.

\section{Authors' information}

GK is a Research Fellow, MH is a Senior Research Officer and YZ is the Head of the laboratory and an Associate Director of the Institute's Strategic Research Program at the Temasek Life Sciences Laboratory, 1 Research Link, NUS, Singapore 117604 and an Adjunct Assistant Professor of the Department of Biological Sciences, 14 Science Drive, National University of Singapore, Singapore 117543, Republic of Singapore.

\section{Acknowledgements}

The authors thank Yan Hong and Chengxin Yi for providing seeds of J. curcas cultivar MD44 and Chengxin Yi and Shilu Zhang for their assistance with bioassay. This work was supported by Singapore Economy Development Board (EDB) and Joil Pte Ltd, Singapore.

Received: 6 December 2013 Accepted: 10 April 2014

Published: 3 May 2014

\section{References}

1. Schnepf E, Crickmore N, Van Rie J, Lereclus D, Baum J, Feitelson J, Zeigler D, Dean D: Bacillus thuringiensis and its pesticidal crystal proteins. Microbiol Mol Biol Rev 1998, 62:775-806.

2. Tojo A, Aizawa K: Dissolution and degradation of Bacillus thuringiensis $\delta$-endotoxin by gut juice protease of the silkworm Bombyx mori. Appl Environ Microbiol 1983, 45:576-580.

3. Milne R, Kaplan H: Purification and characterization of a trypsin-like digestive enzyme from spruce budworm (Chroristoneura fumiferana) responsible for the activation of $\delta$-endotoxin from Bacillus thuringiensis. Insect Biochem Mol Biol 1993, 23:663-673.

4. Knowles BH, Dow JA: The crystal $\delta$-endotoxins of Bacillus thuringiensis: Models for their mechanism of action on the insect gut. Bioessays 1993, 15:469-476

5. Sacchi VF, Parenti P, Hanozet GM, Giordana B, Lüthy P, Wolfersberger MG: Bacillus thuringiensis toxin inhibits $\mathrm{K}^{+}$-gradient-dependent amino acid transport across the brush border membrane of Pieris brassicae midgut cells. FEBS Lett 1986, 204:213-218.

6. Wolfersberger MG: Neither barium nor calcium prevents the inhibition by Bacillus thuringiensis $\delta$-endotoxin of sodium or potassium gradient dependent amino acid accumulation by tobacco hornworm midgut brush border membrane vesicles. Arch Insect Biochem Physiol 1989, 12:267-277

7. Barton KA, Whiteley $\mathrm{H}$, Yang N-S: Bacillus thuringiensis delta-endotoxin expressed in transgenic Nicotiana tabacum provides resistance to lepidopteran insects. Plant Physiol 1987, 85:1103-1109.

8. Vaeck M, Reynaerts A, Höfte H, Jansens S, De Beuckeleer M, Dean C, Zabeau M, Montagu MV, Leemans J: Transgenic plants protected from insect attack. Nature 1987, 328:33-37.

9. Kumar S, Chandra A, Pandey K: Bacillus thuringiensis (Bt) transgenic crop: an environment friendly insect-pest management strategy. J Environ Biol 2008, 29:641-653.

10. Kleiner K, Ellis D, McCown B, Raffa K: Field evaluation of transgenic poplar expressing a Bacillus thuringiensis $\operatorname{cry} 1 \mathrm{~A}(\mathrm{a}) \delta$-endotoxin gene against forest tent caterpillar (Lepidoptera: Lasiocampidae) and gypsy moth (Lepidoptera: Lymantriidae) following winter dormancy. Environ Entomol 1995, 24:1358-1364.

11. McCown B, McCabe D, Russell D, Robison D, Barton K, Raffa K: Stable transformation of Populus and incorporation of pest resistance by electric discharge particle acceleration. Plant Cell Rep 1991, 9:590-594.

12. Dandekar AM, McGranahan GH, Vail PV, Uratsu SL, Leslie C, Tebbets JS: Low levels of expression of wild type Bacillus thuringiensis var. kurstaki cry1A(c) sequences in transgenic walnut somatic embryos. Plant Sci 1994, 96:151-162.

13. Shin D-I, Podila GK, Huang Y, Karnosky DF: Transgenic larch expressing genes for herbicide and insect resistance. Can J Forest Res 1994, 24:2059-2067. 
14. Ellis D, McCabe D, McInnis S, Ramachandran R, Russell D, Wallace $K$, Martinell B, Roberts D, Raffa K, McCown B: Stable transformation of Picea glauca by particle acceleration. Bio/Technology 1993, 11:84-89.

15. Peña $L$, Séguin $A$ : Recent advances in the genetic transformation of trees. Trends Biotechnol 2001, 19:500-506.

16. Tang W, Tian Y: Transgenic loblolly pine (Pinus taeda L.) plants expressing a modified $\delta$-endotoxin gene of Bacillus thuringiensis with enhanced resistance to Dendrolimus punctatus Walker and Crypyothelea formosicola Staud. J Exp Bot 2003, 54:835-844.

17. Harcourt R, Kyozuka J, Floyd R, Bateman K, Tanaka H, Decroocq V, Llewellyn D, Zhu X, Peacock W, Dennis E: Insect-and herbicide-resistant transgenic eucalyptus. Mol Breed 2000, 6:307-315.

18. Génissel A, Leplé J-C, Millet N, Augustin S, Jouanin L, Pilate G: High tolerance against Chrysomela tremulae of transgenic poplar plants expressing a synthetic cry3Aa gene from Bacillus thuringiensis ssp tenebrionis. Mol Breed 2003, 11:103-110.

19. Gubitz GM, Mittelbach M, Trabi M: Exploitation of the tropical oil seed plant Jatropha curcas L. Bioresour Technol 1999, 67:73-82.

20. Datinon B, Glitho A, Tamò M, Amevoin K, Goergen G, Kpindou O: Inventory of major insects of Jatropha curcas L.(Euphorbiaceae) and their natural enemies in Southern Benin. J Agric Biol Sci 2013, 8:711-718.

21. Grimm C: Evaluation of damage to physic nut (Jatropha curcas) by true bugs. Entomol Exp App/ 1999, 92:127-136.

22. Prabhakar M, Prasad Y, Rao G, Venkateswarlu B: A new record of longicorn beetle, Acanthophorus rugiceps, from India as a root borer on physic nut, Jatropha curcas, with a description of life stages, biology, and seasonal dynamics. J Insect Sci 2012, 12:141.

23. Rodrigues SR, Oliveira HN, Santos W, Abot AR: Biological aspects and damage of Pachycoris torridus on physic nut plants. Bragantia 2011, 70:356-360

24. Shanker C, Dhyani S: Insect pests of Jatropha curcas $L$. and the potential for their management. Curr Sci 2006, 91:162-163.

25. Srinivasa Rao C, Pavani Kumari M, Wani SP, Marimuthu S: Occurrence of black rot in Jatropha curcas L. plantations in India caused by Botryosphaeria dothidea. Curr Sci 2011, 100:1547-1549.

26. Gao S, Qu J, Chua N-H, Ye J: A new strain of Indian cassava mosaic virus causes a mosaic disease in the biodiesel crop Jatropha curcas. Arch Virol 2010, 155:607-612

27. Alford DV: A textbook of agricultural entomology. 1st edition. Blackwell Science Ltd; 1999.

28. Waterhouse D: The major arthropod pests and weeds of agriculture in Southeast Asia: distribution, importance and origin. Canberra, Australia: Australian Centre for International Agricultural Research; 1993.

29. Rianti $P$, Suryobroto B, Atmowidi T: Diversity and effectiveness of insect pollinators of Jatropha curcas L. (Euphorbiaceae). HAYATIJ Biosci 2010, 17:38

30. Vakenti J, Campbell C, Madsen H: A strain of fruittree leafroller, Archips argyrospilus (Lepidoptera: Tortricidae), tolerant to azinphos-methyl in an apple orchard region of the Okanagan Valley of British Columbia. Can Entomologist 1984, 116:69-73.

31. Sorensen A, Falcon L: Comparison of microdroplet and high volume application of Bacillus thuringiensis on pear: suppression of fruit tree leafroller (Archips argyrospilus) and coverage on foliage and fruit. Environ Entomol 1980, 9:350-358.

32. AliNiazee M: Evaluation of Bacillus thuringiensis against Archips rosanus (Lepidoptera: Tortricidae). Can Entomologist 1974, 106:393-398.

33. Tu J, Zhang G, Datta K, Xu C, He Y, Zhang Q, Khush GS, Datta SK: Field performance of transgenic elite commercial hybrid rice expressing Bacillus thuringiensis delta-endotoxin. Nat Biotechnol 2000, 18:1101-1104.

34. Qiu C, Sangha JS, Song F, Zhou Z, Yin A, Gu K, Tian D, Yang J, Yin Z: Production of marker-free transgenic rice expressing tissue-specific $B t$ gene. Plant Cell Rep 2010, 29:1097-1107.

35. Qu J, Mao H-Z, Chen W, Gao S-Q, Bai Y-N, Sun Y-W, Geng Y-F, Ye J: Development of marker-free transgenic Jatropha plants with increased levels of seed oleic acid. Biotechnol Biofuels 2012, 5:10.

36. Sreekala C, Wu L, Gu K, Wang D, Tian D, Yin Z: Excision of a selectable marker in transgenic rice (Oryza sativa L.) using a chemically regulated Cre/loxP system. Plant Cell Rep 2005, 24:86-94

37. Yin Z, Wang G-L: Evidence of multiple complex patterns of T-DNA integration into the rice genome. Theor App/ Genet 2000, 100:461-470.
38. Wang Y, Hu H, Huang J, Li J, Liu B, Zhang G: Determination of the movement and persistence of $\mathrm{Cry} 1 \mathrm{Ab} / \mathrm{Ac}$ protein released from $B t$ transgenic rice under field and hydroponic conditions. Soil Biol Biochem 2013, 58:107-114.

39. Mao H, Ye J, Chua N: Genetic transformation of Jatropha curcas. In International Application No: PCT/SG2009/000479 USA; 2009.

40. Gu K, Chiam H, Tian D, Yin Z: Molecular cloning and expression of heteromeric ACCase subunit genes from Jatropha curcas. Plant Sci 2011, 180:642-649.

41. Gu K, Yi C, Tian D, Sangha JS, Hong Y, Yin Z: Expression of fatty acid and lipid biosynthetic genes in developing endosperm of Jatropha curcas. Biotechnol Biofuels 2012, 5:1-15.

42. Bradford MM: A rapid and sensitive method for the quantitation of microgram quantities of protein utilizing the principle of protein-dye binding. Anal Biochem 1976, 72:248-254.

doi:10.1186/1754-6834-7-68

Cite this article as: Gu et al:: Production of marker-free transgenic Jatropha curcas expressing hybrid Bacillus thuringiensis $\delta$-endotoxin Cry $1 \mathrm{Ab} / 1 \mathrm{Ac}$ for resistance to larvae of tortrix moth (Archips micaceanus). Biotechnology for Biofuels 2014 7:68.

\section{Submit your next manuscript to BioMed Central and take full advantage of:}

- Convenient online submission

- Thorough peer review

- No space constraints or color figure charges

- Immediate publication on acceptance

- Inclusion in PubMed, CAS, Scopus and Google Scholar

- Research which is freely available for redistribution
C) Biomed Central 